\title{
Keeping millennials from quitting due to work stress: The roles of mattering, commitment and entrepreneurship orientation
}

\author{
Kususanto Ditto Prihadi, Calvin K.W. Chang, Goo Lyann \\ Center of Cyberpsychology and Games, Department of Psychology, HELP University, Malaysia
}

\begin{abstract}
Article Info
Article history:

Received Jan 19, 2021

Revised Mar 2, 2021

Accepted Mar 15, 2021

\section{Keywords:}

Entrepreneurial orientation Mattering

Mental health at work Organizational commitment Turnover intention

ABSTRACT

Studies in pre-pandemic era had established that millennial workers tend to leave their job due to low organizational commitment or strong entrepreneurial orientation; however, the pandemic had brought down economy due to lockdowns, work stress and mental health instability, limitation of business hours, working from home policy, downsizing of companies, and many other changes. This situation might contribute to a novel situation among millennial employees and their turnover intention might be developed differently. Because mattering has protective feature against work stress and depression, we hypothesized that their it will negatively contribute to their turnover intention, and this contribution is mediated by the organizational commitment. Furthermore, we also hypothesized that this phenomenon would only occur in the condition of lower levels of entrepreneurial orientation. Data was collected from 354 purposively recruited millennial employees who responded to the scales of mattering, organizational commitment, entrepreneurial orientation and turnover intention through online surveys Analyses were conducted with Bootstrap Method in PROCESS Macro Model 10. The findings indicated that the moderated mediation occurred; organizational commitment fully mediated the link between mattering and turnover intention among participants with moderate and high levels of entrepreneurial orientation.
\end{abstract}

This is an open access article under the $\underline{C C B Y-S A}$ license.

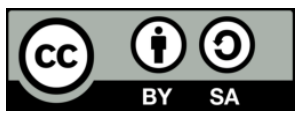

\section{Corresponding Author:}

Kususanto Ditto Prihadi

Center of Cyberpsychology and Games, Department of Psychology

Higher Education Learning Philosophy (HELP) University

Selangor, Malaysia

Email: prihadi.k@help.edu.my

\section{INTRODUCTION}

In the last few decades, organizations have been downsized in order to survive financial turbulences and increase efficiency [1]. Nevertheless, smaller size of organizations might lead to higher workload that causes burnout and dissatisfaction among employees [2], which might put the employees' mental health at risk [3], [4] and ended up in higher turnover intention [5]. Turnover intention among employees signifies more problems nowadays with smaller, highly-efficient organizations, because the workload has been optimally distributed [6], [7]. For employees from the millennial generation (born between 1983 and 2000), job-hopping was considered a common practice in order to get into the position they are satisfied with [8]; however, in the midst of pandemic, keeping the existing job has already been a challenging tasks for millennials and finding a new, higher-paying organization was even more challenging [9]. Moreover, the employees' mental health and workload are becoming uncertain in the midst of pandemic due to the governmental policies on lockdown, quarantine, work-from-home, downsizing, or limited business hours [10], [11]. 
With an exception of the Americans, millennial workers around the world were known to be entrepreneurial, less committed to the organizations they work for, and therefore developed higher turnover intention since when they were newly recruited [12], [13]. The same studies also reported that younger millennial employees tend to be less resilient and vulnerable to burnout, job stress, and other mental health problems, which eventually lead to their turnover intention. This tendency is considered more severe during the pandemic era in 2020, where most of them were working from home, because their mental health stability is highly dependent on the social feedback they use to receive regularly in the workplace [14].

In the recent pre-pandemic era, the main predictors of high turnover intention among millennials were either lower levels of organizational commitment due to mental perceived mental health-related issues [15]-[18] or high levels of entrepreneurial orientation [19], [20]. The two factors were significant because the millennials perceived that they deserve a better work-life balance, and that they have the skills required by the new companies; furthermore, many startup companies developed by millennials would prefer to hire millennial employees. Nevertheless, during the pandemic, economic downturn was inevitable and the opportunities to jobhop are no longer openly available. The aforementioned literature indicated that the development of turnover intention among white collared millennials is taking a new form, and this current study aims to propose a novel moderated mediation model of the turnover intention development among millennials.

In the context of this current study, we chose the sense of mattering as our main predictor, because previous recent studies had established its robustness as protective factors of mental health at work. For instance, during the pandemic, work self-efficacy (the belief that one is capable to do their work well) was reported to be predicted by the sense of mattering [21]. Mattering was also reported to be the protective factor against depression symptoms and suicide ideation among young adults [22], [23]. The decision to involve mattering as our main predictor in this current study is also confirmed because it has been established that employees with higher levels of mattering tend to have higher job satisfaction, perceive lower job stress, as well as perceive higher work-life balance [4], [24], [25] that will lead to lower turnover intention [26]. Our second choice as the predictor of turnover intention was the organizational commitment. From the aforementioned literature in the previous paragraph, we learned that employees with higher organizational commitment tend to develop less turnover intention. Nevertheless, organizational commitment was discovered was also discovered to be significantly predicted by the levels of mattering [27], [28], therefore we put it as our mediator variable. In other words, we hypothesized that employees who believe that they matter to their organizations would likely to be more committed to their organization, and therefore, would less likely to develop turnover intention. Literature also suggested the involvement of entrepreneurial orientation, because it is common among millennial employees and it was reported to be a significant predictor of turnover intention [19], [20], [29], [30]. The hypothetical model is illustrated in Figure 1.

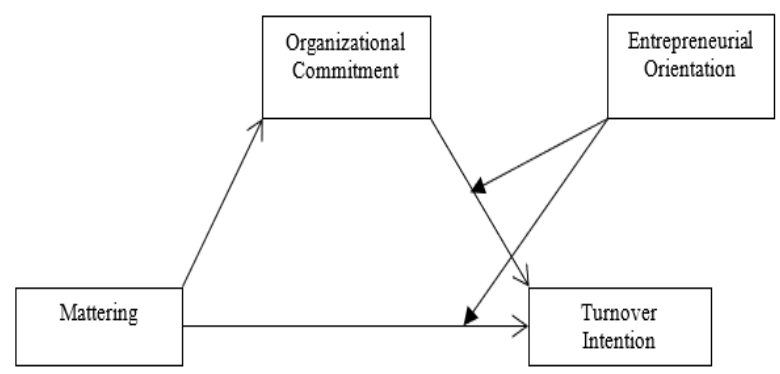

Figure 1. Moderated mediation hypothesis

\section{RESEARCH METHOD}

Survey design was employed in this empirical study. Purposive sampling method was utilized in order to select and recruit 400 Malaysian millennial employees across private and governmental organizations. Link to an online questionnaire was distributed through social media with a professional help of a market research institution, and an informed consent form was provided at the first page of the survey. The participants were rewarded with five Malaysian Ringgit Grab Food Vouchers if they respond to the online survey. Data from 400 individuals was collected, but due to age limit and nationality issues, only 354 are included. Scales utilized in the survey to were General Mattering Scale [31], Organizational Commitment Scale [32], Individual Entrepreneurial Orientation Scale [33], and Turnover intention scale [34]; Cronbach Alpha of each scale was $.87, .86, .98$, and .77 respectively. Data were analyzed by using Bootstrap method with 5,000 samples with 95\% of confidence interval, executed with PROCESS Macro model 8 in SPSS. 


\section{RESULTS}

Bootstrap Method with 5000 samples was conducted through PROCESS Macro Model 14 in order to test the moderated mediation hypothesis. The following Table 1 indicates the significance of relationship among the variables.

Table 1. The total effect, interaction effect and direct effect

\begin{tabular}{lccccccccc}
\hline & $\mathrm{R}^{2}$ & $\beta$ & $\mathrm{se}$ & $\mathrm{t}$ & $\mathrm{df1}$ & $\mathrm{df} 2$ & $\mathrm{p}$ & LLCI & ULCI \\
\hline $\mathrm{X} \rightarrow \mathrm{M}$ & .24 & .80 & .08 & 10.52 & 1.00 & 353.00 & $.00^{*}$ & .65 & .96 \\
$\mathrm{X} \rightarrow \mathrm{Y}$ & .28 & -.01 & .01 & -.69 & 4.00 & 350.00 & .49 & -.03 & -.02 \\
$\mathrm{M} \rightarrow \mathrm{Y}$ & .28 & -.08 & .04 & -2.33 & 4.00 & 350.00 & $.02^{*}$ & -.15 & -.01 \\
$\mathrm{~W} \rightarrow \mathrm{Y}$ & .28 & -.20 & .08 & -2.65 & 4.00 & 350.00 & $.01^{*}$ & -.35 & -.05 \\
$\mathrm{Int}(\mathrm{M}, \mathrm{W}) \rightarrow \mathrm{Y}$ & .28 & .00 & .00 & 3.63 & 4.00 & 350.00 & $.00^{*}$ & .00 & .00 \\
\hline $\mathrm{X}=$ Mattering & & & & & & & \\
$\mathrm{M}=$ Organizational Commitment & & & & & & \\
$\mathrm{Y}=$ Turnover Intention \\
$\mathrm{W}=$ Entrepreneurial Orientation
\end{tabular}

Table 1 explain that mattering did not have any direct significant effect to the turnover intention. On the other hand, a significant, yet weak direct effect was shown by organizational commitment, and the direction was negative. Entrepreneurial orientation indicated a stronger negative significant effect on the organizational commitment. Furthermore, the interaction between organizational commitment and entrepreneurial orientation posed a weaker, yet significant, positive effect on turnover intention. The indirect relationship, or the moderated-mediation hypothesis was tested, and the results are depicted in Table 2.

Table 2. The indirect effect and the moderated-mediation

\begin{tabular}{lccccc}
\hline & $\mathrm{W}$ & Effect & BootSE & BootLLCI & BootULCI \\
\hline $\mathrm{X} \rightarrow \mathrm{M} \rightarrow \mathrm{Y}$ at low W & 30.00 & .02 & .01 & -.00 & .03 \\
$\mathrm{X} \rightarrow \mathrm{M} \rightarrow \mathrm{Y}$ at moderate W & 36.00 & .03 & .01 & $.02^{*}$ & $.04^{*}$ \\
$\mathrm{X} \rightarrow \mathrm{M} \rightarrow \mathrm{Y}$ at high W & 43.00 & .05 & .01 & $.03^{*}$ & $.07^{*}$ \\
\hline $\mathrm{X}=$ Mattering & & & & & \\
$\mathrm{M}=$ Organizational Commitment & & & & \\
$\mathrm{Y}=$ Turnover Intention & & & \\
$\mathrm{W}=$ Entrepreneurial Orientation & & & \\
$*=$ Significant; there is no zero between the lower and upper levels of bootstrap confidence interval
\end{tabular}

As shown in Table 2, moderated mediation occurred. The indirect effect of mattering through organizational commitment significantly predicted turnover intention only in the condition of moderate and high entrepreneurial orientation, where there is no zero along the range between lower limit and upper limit of bootstrap confidence interval. This range contains zero when the level of entrepreneurial orientation was low. In other word, results of the statistical analyses support our moderated mediation hypothesis. It can be summarized that among employees with moderate to high entrepreneurial orientation, the more they feel that they matter to the organization, the higher their commitment would be, and they will develop higher intention to leave.

\section{DISCUSSION AND IMPLICATION}

Before discussing any further on our findings, we would like to state that this study was not without limitation. First of all, the data was collected in the midst of national lockdown situation in Malaysia, where most employees had to work from their homes. Moreover, the pandemic situation also altered the landscape of entrepreneurial landscape by adding the uncertainty in most business areas; this might seriously affect our participants in responding to any questions regarding entrepreneurship. Furthermore, organizations were shrinking due to the economic uncertainty related to the pandemic, which might affect the organizational commitment among our participants. Thus, results of this current study might not be generalized to different settings. Secondly, the participants were limited to white collared employees in urban area of Malaysia, without any job specification or other specification related to their lines of industry; therefore, our findings might only be applicable to general population, instead of specific fields of industry. Third, apart from mattering, variables with immediate link to mental health, such as stressors, stress, or burnout might be required to explain the studied phenomenon better. Therefore, we suggested for the future research to consider the aforementioned limitations. The following paragraphs discuss the findings of this current study.

Our hypothesis was supported by the data we have collected. This indicated that some elements of our findings are consistent to the previous studies, and some others are not. For instance, our data suggested that 
mattering did not have any direct effect on turnover intention. This is inconsistent with some findings, such as the one by Richards et al [4], Haizlip et al. [28], as well as Reece et al. [3], who stated that the sense of mattering at work predicts the general mental well-being at work, protect the employees from burnout and work-related stress, two main predictors of turnover intention [5], [35]-[37]. In our defense, despite we agree that mattering holds a key role in mental health at work, we did not try to prove it any further. Instead, we attempt to see further implication of mattering's role in mental health at work by linking it to the development of turnover intention.

Nevertheless, the overall finding of our study can be considered consistent to the previous aforementioned findings. Moreover, we suggested that mattering at work contributed to the employees' turnover intention, but it will not affect their intention to stay or to leave before they develop a higher commitment to the organization. The part of our findings where mattering positively predicted organizational commitment consistent to the recent findings, which stated that organizational commitment is also derived from a better mental health at work, which is promoted by the sense of mattering [27], [28]. Our confirmed significant link between the organizational commitment and turnover intention is in line with the recent findings in Asian settings, such as the work of Santi et al. [15], Wardana et al. [16], Li et al. [17] and Park [18].

While the mediation part of our finding seemed to be consistent with the previous recent studies, things changed when we involve the moderation part of our findings. The involvement of entrepreneurial orientation as the moderator changed the direction of the relationship between the organizational commitment and turnover intention; when the employees are moderately or highly oriented towards entrepreneurship, the more they are committed to their organization, the more they built the intention to leave it. This consistency can be justified by stating that none of the aforementioned recent studies in the previous paragraph involved entrepreneurial orientation into their equations; nevertheless, we still need to explain the reason employees with higher commitment to the organization would develop higher intention to leave when they have higher entrepreneurial orientation, and that the commitment does not significantly predict turnover intention among those with low entrepreneurial orientation. The explanation is discussed in the next paragraph.

The work of Zhu et al. [20] explained that the relationship between entrepreneurial orientation partially mediates the relationship between high performance work systems and organizational performance, which suggested the significant contribution of the organizational commitment as the element of performance on entrepreneurial orientation. Confirming that, Marshall and Gigliotti in 2020 [19] explained that while entrepreneurial orientation might be started at younger age, it will be more polished within the organization. These two examples of recent past studies confirmed that employees with higher organizational commitment who possess higher entrepreneurial orientation would likely to develop stronger intention to leave the organization.

Another highlight of our current study is the fact that mattering played important role in the development of organizational commitment as the product of employee mental health. The fact that our findings suggested that mattering has a direct significant effect on employee's organizational commitment confirmed that mattering plays significant role in protecting employees' mental health [4], because mental health is positively related to organization commitment [38]. Thus, in the context of our study, it can be stated that the level of mattering among employees protects their mental health stability and predicts their organizational commitment, which eventually develop higher turnover intention among those with moderate to high levels of entrepreneurial orientation.

\subsection{Implication}

It is important to note, however, that turnover intention does not always come hand-to-hand with the actual turnover; turnover intention is significantly predicted by poor mental health at work, such as stressful situation, while the actual turnover is predicted by the source of the stress, such as workload or social treatment [26]. In the context of our study, turnover intention was promoted by the entrepreneurial orientation, a variable that is considered controversial due to its impact on the job performance and turnover intention. For instance, two studies in 2020 reported that employees with stronger entrepreneurial orientation were more likely to be engaged and committed to their organization, but at the same time also more likely to be considering starting their own business, leading to a conflicting relationship to turnover intentions [29], [30].

Thus, the main implication of our finding is that mattering remains as an important predictor of mental health at work, because it was still a positive significant predictor of organizational commitment, which is an indicator of mental health at work. Nevertheless, employees with more stable mental health and stronger commitment to the organization might still develop higher turnover intention if they possess higher levels of passion to start their own businesses. This type of turnover intention might have positive impact on the organization before the employee actually quits, because their entrepreneurial orientation contributes positively to their organizational performance [29]. In the midst of pandemic and uncertainty, opportunities rises for social entrepreneurship and seems to be halted for non-social entrepreneurship [39], [40], therefore entrepreneurial employees who do not possess any direction towards social entrepreneurship might not make 
haste to leave the company despite having higher turnover intention. This type of employees can be trained to channel their entrepreneurial orientation inward to improve the organizational performance.

\section{CONCLUSION}

The novelty point that we offer in this current study lies on the role of mattering and entrepreneurial orientation as factors in predicting turnover intentions. Many turnover intention studies in the past tend to put mental health-related factors, such as burnout, workload stress, and stressors, while this current study took further step in investigating how the product of work mental health, which is organizational commitment, contribute to turnover intention. Moreover, we also took into account another variable that commonly present among millennial employees, entrepreneurial orientation, which was proven to be an important changing agent in determining the development of turnover intention. It is safe to conclude that the novel finding of this current study is that despite higher levels of mattering might protect employees from mental health issues and increases their organizational commitment, their turnover intention might still be increased when they have moderate to high entrepreneurial orientation.

\section{ACKNOWLEDGEMENTS}

This study is funded by the Internal Research Grant Scheme from Research Management Center, ELM Graduate School, HELP University. ID\#20-03-008.

\section{REFERENCES}

[1] G. L. Cohee, “Corporate downsizing: Getting our policy right," Organizational Dynamics, vol. 48, no. 1, pp. 38-43, 2019, doi: 10.1016/j.orgdyn.2018.01.004.

[2] D. Gharakhani and A. Zaferanchi, "The effect of job burnout on turnover intention with regard to the mediating role of job satisfaction," Journal Health, vol. 10, no. 1, pp. 109-117, 2019.

[3] A. Reece et al., "Mattering is an indicator of organizational health and employee success," The Journal of Positive Psychology, 2019, doi: 10.1080/17439760.2019.1689416.

[4] K. A. R Richards, N. S. Washburn, and M. A. Hemphill, "Exploring the influence of perceived mattering, role stress, and emotional exhaustion on physical education teacher/coach job satisfaction," European Physical Education Review, vol. 25, no. 2, pp. 389-408, May 2019, doi: 10.1177/1356336X17741402.

[5] B. Wen, X. Zhou, Y. Hu, and X. Zhang, "Role Stress and Turnover Intention of Front-Line Hotel Employees: The Roles of Burnout and Service Climate," Frontiers Psychology, vol. 11, p. 36, 2020, doi: 10.3389/fpsyg.2020.00036.

[6] J. Oh and S. Oh, "Authentic leadership and turnover intention: does organizational size matter?," Leadership \& Organization Development Journal, vol. 38, no. 7, pp. 912-926, 2017, doi: 10.1108/LODJ-08-2016-0209.

[7] A. Junaidi, E. Sasono, W. Wanuri, and D. W. Emiyati, "The effect of overtime, job stress, and workload on turnover intention," Management Science Letters, vol. 10, no. 16, pp. 3873-3878, 2020.

[8] M. Harris, L. Williams, and R. Duke, "The millennial engagement, resiliency and retention study: What does your millennial advanced practice registered nurse workforce really want?," Journal American Association Nurse $\begin{array}{lll}\text { Practitioners, } 2020 . & \text { [Online]. Available: }\end{array}$ https://journals.lww.com/jaanp/Abstract/9000/The_millennial_engagement,_resiliency_and.99448.aspx.

[9] Y. Brigita Saerang and K. D. H Saraswati, "The Role of Psychological Capital, Quality of Work Life, and Perceived Job Opportunity on Turnover Intention in Millennials (Study on PT. X Business Unit)," in Tarumanagara International Conference on the Applications of Social Sciences and Humanities, 2019, pp. 534-541.

[10] J. A. Phillips, "Work-Life Fit During A Pandemic," Workplace Health and Safety, vol. 68, no. 10, pp. 502-503, Oct. 01, 2020, doi: 10.1177/2165079920953830.

[11] J. Stogner, B. L. Miller, and K. McLean, "Police Stress, Mental Health, and Resiliency during the COVID-19 Pandemic," American Journal of Criminal Justice, vol. 45, no. 4, pp. 718-730, 2020, doi: 10.1007/s12103-020-09548-y.

[12] M. Rodriguez, S. Boyer, D. Fleming, and S. Cohen, "Managing the next generation of sales, gen z/millennial cusp: an exploration of grit, entrepreneurship, and loyalty, " Journal of Business-to-Business Marketing, vol. 26, no. 1, pp. 43-55, 2019, doi: 10.1080/1051712X.2019.1565136.

[13] E. M. Struckell, "Millennials: A Generation of Un-Entrepreneurs," Journal of Business Diversity., vol. 19, no. 2, p. 2019, 2019, doi: 10.33423/jbd.v19i2.2062.

[14] K. D. Prihad.i, E. S. Z. Lim, and E. Sim, "Mattering and life satisfaction among the quarantined adults in Malaysia during the COVID-19 pandemic," International Journal Public Heatlh Science, vol. 10, no. 1, pp. 189-193, 2021, doi: 10.11591/ijphs.v10i1.20684.

[15] M. W. Santi, N. Nandini, and G. Alfiansyah, "The effect of burnout syndrome on turnover intention using organizational commitment as an intermediate variable/ Pengaruh Burnout Syndrome Terhadap Turnover Intention dengan Komitmen Organisasi Sebagai Variabel Perantara," Jurnal Administrasi Kesehatan Indonesia, vol. 8, no. 2, 2020, doi: 10.20473/jaki.v8i2.2020.109-122.

[16] M. Chudri Wardana, R. Anindita, and R. Indrawati, "Work Life Balance, Turnover Intention, And Organizational Commitment in Nursing Employees at X Hospital, Tangerang, Indonesia," Kemalapublisher.com, vol. 4, no. 4, 2020. [Online]. Available: https://kemalapublisher.com/index.php/JoMA/article/view/474.

[17] N. Li, L. Zhang, G. Xiao, Z. J. Chen, and Q. Lu, "Effects of organizational commitment, job satisfaction and

Keeping millennials from quitting due to work stress: the roles of mattering ... (Kususanto D. Prihadi) 
workplace violence on turnover intention of emergency nurses: A cross-sectional study,” Int. J. Nurs. Pract., vol. 26, no. 6, Dec. 2020, doi: 10.1111/ijn.12854.

[18] H. S. Park, "정신간호사의 셀프리더십과 조직몰입이 재직의도에 미치는 영향/Impact of Self-leadership and Organizational Commitment on the Intention of Psychiatric Mental Health Nurses to Remain in the Profession," Journal Korean Acad Psychiatry Mental Health. Nursing, vol. 25, no. 4, pp. 409-417, 2016, doi: 10.12934/jkpmhn.2016.25.4.409.

[19] D. R. Marshall and R. Gigliotti, "Bound for entrepreneurship? A career-theoretical perspective on entrepreneurial intentions," The International Entrepreneurship and Management Journal, vol. 16, no. 1, pp. 287-303, 2020.

[20] C. Zhu, A. Liu, and G. Chen, "High performance work systems and corporate performance: the influence of entrepreneurial orientation and organizational learning," Frontiers Business Research China, vol. 12, no. 1, 2018, doi: 10.1186/s11782-018-0025-y.

[21] K. D. Prihadi, E. S. Z. Lim, and C. Chan., "Efficacy of working from home among urban professionals in Malaysia during the pandemic: The robust predictive role of mattering," International Journal Public Health Science, vol. 10, no. 1, pp. 215-220, 2021, doi: 10.11591/ijphs.v10i1.20736.

[22] G. L. Flett, A. Khan, and C. Su, "Mattering and Psychological Well-being in College and University Students: Review and Recommendations for Campus-Based Initiatives," The International Journal of Mental Health and Addiction, vol. 17, no. 3, pp. 667-680, 2019, doi: 10.1007/s11469-019-00073-6.

[23] K. Prihadi, C. Y. Wong, and K. Y. Chong, "Suicidal thoughts among University students in Malaysia and Indonesia: The role of mattering, state self-esteem and depression level," International Journal of Evaluation and Research in Education, vol. 9, no. 3, pp. 494-502, 2020.

[24] K. A. R. Richards, K. L. Gaudreault, and A. M. Woods, "Understanding physical educators' perceptions of mattering: Validation of the Perceived Mattering Questionnaire - Physical Education," European Physical Education Review, vol. 23, no. 1, pp. 73-90, 2017, doi: 10.1177/1356336X16637320.

[25] G. L. Flett, "Resilience to Interpersonal Stress: Why mattering matters when building the foundation of mentally healthy schools," in Handbook of School-Based Mental Health Promotion, pp. 383-410, 2018.

[26] S. Fukui, A. L. Rollins, and M. P. Salyers, "Characteristics and job stressors associated with turnover and turnover intention among community mental health providers," Psychiatric Services, vol. 71, no. 3, pp. 289-292, 2020.

[27] N. M. Boyd and B. Nowell, "Sense of community, sense of community responsibility, organizational commitment and identification, and public service motivation: a simultaneous test of affective states on employee well-being and engagement in a public service work context," Public Management Review, vol. 22, no. 7, pp. 1024-1050, 2020, doi: 10.1080/14719037.2020.1740301

[28] Haizlip, J., McCluney, C., and Hernandez, M., "Mattering: how organizations, patients, and peers can affect nurse burnout and engagement," The Journal of Nursing Administration| JONA, vol. 50, no. 5, pp. 267-273, 2020.

[29] G. Ahmetoglu, V. Nefyodova, and T. Chamorro-Premuzic, "What Leads Entrepreneurial Employees to Want to Quit, or Stay in, Their Job? Exploring Two Conflicting Mechanisms," Applied Psychology, pp. 1-21, 2020. doi: 10.1111/apps.12250.

[30] B. Bulmash and M. Winokur, "Entrepreneurial passion and turnover intentions: The role of intrapreneurship opportunities and risk tolerance," IEEE International Conference on Industrial Technology (ICIT), 2020. [Online]. Available: https://ieeexplore.iee.org/abstract/document/9067259/.

[31] H. I. Sari and M. A. Karaman, "Gaining a Better Understanding of General Mattering Scale: An Application of Classical Test Theory and Item Response Theory," International Journal of Assessment Tools in Education, vol. 5, no. 4, pp. 668-681, 2018. Doi: 10.21449/ijate.453337.

[32] J. P. Meyer and N. J. Alien, “A three-component conceptualization of organizational commitment," uman Resource Management Review, vol. 1, no. 1, pp. 61-89, 1991, doi: 10.1016/1053-4822(91)90011-Z.

[33] D. L. Bolton and M. D. Lane, "Individual entrepreneurial orientation: development of a measurement instrument," Education and Training, vol. 54, no. 2-3, pp. 219-233, 2012, doi: 10.1108/00400911211210314.

[34] P. Gregory, I. Wilfrid, and D. F. Coleman, "Further assessments of a three-component model of occupational commitment: Generalizability and differences across occupations Another look at the locus of controlorganizational commitment relationship: It depends on the form of commitment View project," Journal of Applied Psychology, vol. 82, no. 33, pp. 444-452, 1997, oi: 10.1037/0021-9010.82.3.444.

[35] J. N. Scanlan et al., "Workplace experiences of mental health consumer peer workers in New South Wales, Australia: A survey study exploring job satisfaction, burnout and turnover intention," BMC Psychiatry, vol. 20, no. 1, p. 270, 2020, doi: 10.1186/s12888-020-02688-9.

[36] H. Wang, Y. Jin, and D. Wang, "Job satisfaction, burnout, and turnover intention among primary care providers in rural China: Results from structural equation modeling," BMC Famil Practice, vol. 21, no. 1, p. 12, 2020.

[37] S. Srivastava and S. Agrawal, "Resistance to change and turnover intention: a moderated mediation model of burnout and perceived organizational support," Journal of Organizational Change Management, vol. 33, no. 7, pp. 1431-1447, Jul. 2020. Doi: 10.1108/JOCM-02-2020-0063.

[38] B. Kim, "Unstable jobs harm performance: The importance of psychological safety and organizational commitment in employees," Sage Journal, vol. 10, no. 2, pp. 1-10, 2020, doi: 10.1177/2158244020920617.

[39] S. Bacq and G. T. Lumpkin, "Social Entrepreneurship and COVID-19," Journal of Management Studies, vol. 8, no. 1, pp. 1-4, 2020, doi: 10.1111/joms.12641.

[40] U. Stephan, P. Zbierowski, and P.-J. Hanard, "Entrepreneurship and COVID-19: Challenges and opportunities An assessment of the short-and long-term consequences for UK small businesses," 2020. [Online]. Available: www.kcl.ac.uk/business 